\title{
Solid Waste Management Practice and Challenges in Gashua, Yobe State, Nigeria
}

\author{
Saleh A. ${ }^{*}$, and Ahmed A. ${ }^{2}$ \\ ${ }^{1}$ Department of Geography, Federal University Gashua, Nigeria \\ ${ }^{2}$ School of Preliminary Studies, Sule Lamido University, Kafin Hausa, Nigeria \\ *Corresponding Author: abbasalehgs@gmail.com, abubakar8550483@gmail.com
}

https://doi.org/10.36263/nijest.2019.02.0139

\begin{abstract}
This paper presents an overview of the current solid waste management practices in Gashua town and provides a brief discussion on future challenges. Gashua town the headquarters of Bade Local Government Area since 1949. Since then the population has mainly due to the influx of people and its strategic location along the axial route to significant towns in the state. Wastes are generated mainly from residential, commercial and institutional land uses. Waste collection sites are strategically situated as identified by the agency and designated as high waste generating points, metal waste bins and constructed waste bunkers. The contents of these bins are finally disposed of at a location 6kilometres away from the generating points. Spatial data on waste distribution was collected using a global positioning system (GPS). The data was manipulated and processed using a Geographic information system (GIS) to produce the waste distribution map. Findings revealed that the existing solid waste management system is inefficient as the present practice relies on monthly collection and disposal of waste using an open dumpsite.
\end{abstract}

Keywords: Practice and Challenges, Solid Waste Management, Gashua, GIS, GPS

\subsection{Introduction}

The generation and management of solid waste is currently a global issue of interest, specifically in the developing nations universally (Chukwuemeka et al, 2012). The recurrent widespread of communicable diseases in both more prominent cities and medium towns are not unconnected with numerous huge garbage littering the streets, dumping of refuse near water bodies and drainage and in vacant plots in Nigeria (United Nations, Department of Economic and Social Affairs, 2014; Birma et al., 2016). Urbanization, population growth, enhanced lifestyle, inadequate planning and inadequate funding are the factors responsible for the increased solid waste management issues (Abila and Kantola, 2013). Nigeria's population growth rate was 3.0\%, and the urban growth rate was at about $5.5 \%$ while waste generation rate was at $0.49 \mathrm{~kg}$ per day as indicated by the National Bureau of Statistics (Afun, 2006). Urban centres in Nigeria are continuously experiencing population increase as well as a steady rise in waste generation due to urbanization (Kula and Gukop, 2012). A city like Abuja, which is the nation's capital, generates a daily waste per person between $0.55-0.58 \mathrm{~kg}$ (Metropolis eta al, 201). In 1995 0.55-0.58 million tons of waste is generated in Lagos state one of the most densely settled cities in the world and 998.08 tons of municipal solid waste is generated in Lagos in 2000 whereas 90 tons of solid waste was generated per day in Minna, the capital of Niger State among others (Amuda et al., 2014; Adetunji et al., 2015).

Most industrialized nations have adopted the "Waste Management Hierarchy" (minimization, recovery and transformation, and disposal) as the list of options for developing solid waste management approaches (El-Haggar, 2007). The extent to which anyone option is used within a given country however varies, depending on some factors, such as topography, population density, and transportation infrastructure, socioeconomic and environmental code of practice (Babalola et al., 2010). One of the most analytical vital instruments for appropriate land use planning in the current dynamic world is waste monitoring and management (Anestina et al, 2014) 
Essentially, solid waste management in Nigeria is under the responsibility of the Local Environmental Protection Agency as stipulated by the 1988 decree which established the Federal Environmental Protection Agency (FEPA) (Agunwamba, 1998; Amasuomo, 2017). The collection of waste in Gashua is carried out by the Yobe State Environmental Protection Agency, (YOSEPA) Sanitary Board and Metropolitan Council. However; these local authorities have been overwhelmed by the increasing rate of waste generation, collection and transportation problems primarily due to overstretched facilities, shortages of the workforce and lean budget (Ogwuleka, 2012).

\subsection{Materials and Methods}

Gashua is a community in Yobe State located in the northeastern region of Nigeria, on the Yobe River, a few miles below the convergence of the Hadejia River and the Jama'are River. The average elevation is about $299 \mathrm{~m}$. The population in 2006 was about 125,000 (Yobe State Government, 2016). The hottest months are March and April, with temperature ranges of $38^{\circ}-43^{\circ}$ Celsius. In the rainy season, June-September, temperatures fall to $23-28^{\circ}$ Celsius, with rainfall of 500 to $800 \mathrm{~mm}$. Gashua is one of the largest and most developed towns in Yobe State. Since 1949 it has been headquarters of the Bade Local Government Area. The Bade language is spoken in Gashua, and an area is fanning out east and south of Gashua. Bade is one of seven languages of the Chadic family indigenous to Yobe State (Abbas, 2016; Yobe State Government, 2016). The town lies near the Nguru-Gashua Wetlands, an economically and ecologically crucial ecological system. The town is the location of the court of Mai Bade, the Emir of Bade (Schuh and Languages, 2015; Djurfeldt et al., 2017).

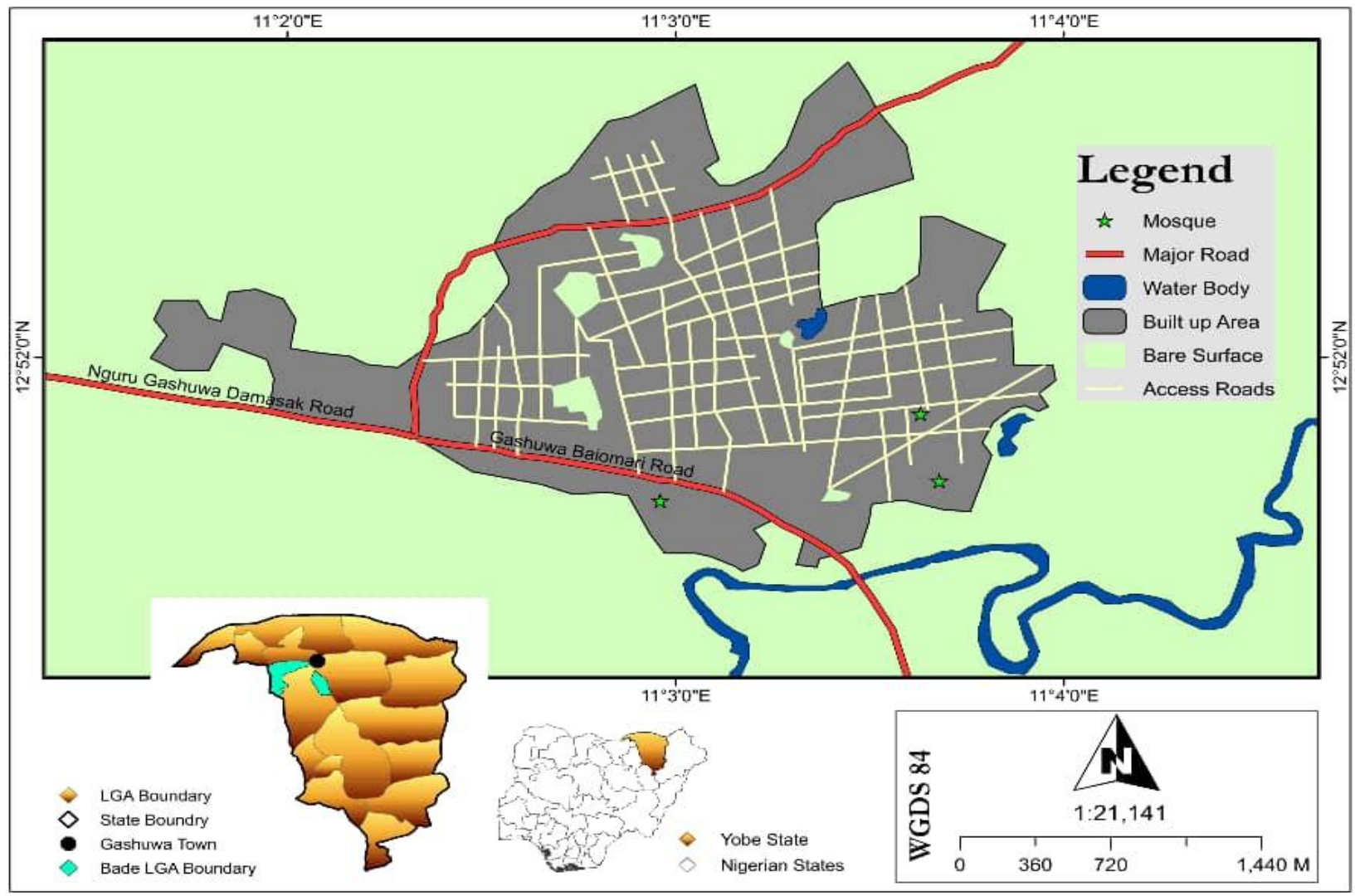

Figure 1: Map of the study area

(Source: Adopted and Modified from the Political Map of Yobe State, 2019)

Gashua town rose from an obscure native authority headquarters to the status of the local government headquarters in 1976. The sudden change in status brought about the increase in population from less than Ten thousand $(10,000)$ persons before 1991 to a Population of about 139, 804 with 73, 709 males and 66, 095 females in 2006 (National population Commission, 2006; WFP, 2016). The rise in the population levels also brought about with it rapid economic growth and consequently the rise in the living standards of the people. Wastes and other contaminants from residential and other land use land uses in Gashua town are highly visible. Currently, domestic solid waste management in Gashua has severe problems, involving low collection rate, unscientific disposal method (open dumping), lack of separation and treatment mechanism in place, and burning of waste dumps without air pollution 
control measures in place. For a better understanding of the present solid waste management scenario in the study area, the paper is structured as follows.

Waste collection bins are placed at strategic locations identified by the agency and termed as high waste generating points with wheeled plastic waste bins, metal waste bins and constructed waste bunkers (Uwadiegwu and Chukwu, 2013). The contents of these bins are finally disposed at a location 6 kilometers away from the generating points (Imam et al., 2008). This method adopted shows that the waste collections are sourced specified the approach in which the individual components of the waste stream are sampled, sorted and weighed. This method is useful for defining a local waste stream. The system adopted by the agency is the public bin collection system. This comprises of the collection from different sources like residential and commercial areas and deposited in the public bins located strategically along street corners of the town. Wastes are not treated before disposal at the final dumping sites. Waste minimization and recycling have not gone beyond the practice of picking and sorting through heaps of refuse or garbage. A retrospective study involves the collection of information from (YOSEPA), the agency responsible for the management of solid waste in the town. Other sources of information include personal observations, interviews with staff of the agency. Relevant information was also sourced from reports, books and journals.

Field surveys were carried out in some areas and the existing official dumpsite on the various samples of waste generated. The field survey involved the use of global positioning system to determine the position of dumpsters in the town. After that, the spatial positions of the waste collection points were produced from the integration of Geographic information system (GIS) and global positioning system (GPS) data. The names and locations (Easting and Northing coordinates) were recorded and stored in Microsoft Excel and converted into a database format and after that exported into Arc info GIS which is concerned with the manipulation of spatial and non-spatial data for processing. A layer of these points was created and then combined with a map layer digitized from the satellite imagery of the study area. Figure 1 shows the spatial distribution of waste collection points. Data on monthly waste collection for the period 2012-2018 were also obtained from the agency responsible for waste management. This served as the basis for comparison and testing the hypothesis.

Other method adopted is site Specific Study Approach which involves dumping sites identification, sorting and weighing of the components of waste products. This methodology is useful in defining a local waste especially when larger samples are taken for several seasons (Walling et al, 2004).

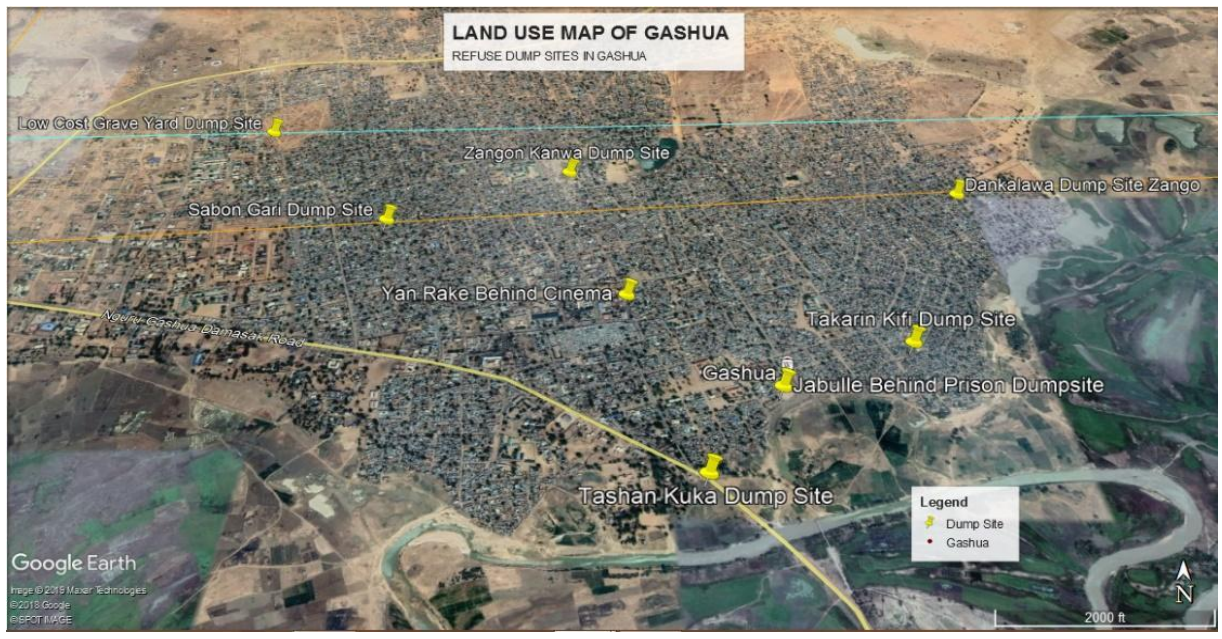

Figure 2: Refuse dump sites in Gashua

(Source: Authors' GIS analysis, 2019)

\subsection{Results and Discussion}

The waste compositions are as follows: Polythene and Plastic materials, 40\% Metal and tins, 5.2\% Organic matter, 54.8\%. Table 1 below revealed the waste collected in Gashua from 2012-2018 On the whole, the agency collected 132, 685 tons of solid waste between the periods under review, considering the average waste generation of $0.3 \mathrm{~kg} /$ person/day. Moreover, the population of Gashua 
of 76,000 persons in 2006 (NPC, 2006) and estimated to be 96,448 persons in 2018(NBS, 2018). It can be seen from Table 2 that virtually every month, the agency collected and disposed of waste within the town, but the amount collected remained very little compared to what is seen in the dumpsters. The amount of waste collected stood at 23, 198 tons in 2012 and 21, 483 tons in 2018. This implies that there was a decline in the amount of waste collected over seven years. Table 2 below shows the descriptive statistics used in the calculating mean monthly waste collection of $95 \%$ significant level. The analysis of variance (ANOVA) was used to test whether the mean weight of solid waste collected is the same for the year 2012, 2013, 2014, 2015 and 2016, 2017 and 2018. The hypothesis can be written as $\left[\mathrm{H}_{0}: \mu_{1}=\mu_{2}=\mu_{3}=\mu_{4}=\mu_{5}=\mu_{6}=\mu_{7}=\mu_{8}\right]$ versus [H1: $\left.\mu: \neq \mu_{\mathrm{j}}\right] \mathrm{H}_{0}: \mu 1=\mu 2$ $=\mu 3=\mu 4=\mu 5=\mu 6=\mu 7=\mu 8$ all mean weight is not the same while, $\mathrm{H1}: \mu: \neq \mu \mathrm{j}$ for at least one of the mean weight is the same. $\mathrm{H}_{0}$ is rejected at the level significance of 0.05 since the value of the $\mathrm{F}$ statistic (4.038) is greater than the critical value of the F statistic, F critical value (2.219). This indicates that there is a significant difference in the amount of waste collected from 2012-2018 at the 0.05 level of significance. From the preceding, it becomes clear that the agency performed below average as heaps of garbage have taken over the access road and thereby causing traffic problems in some parts of the town while the drainage system has been blocked as a result of poor management practices.

Table 1: Solid waste collection from 2012-2018 in Gashua town

\begin{tabular}{lccccccc}
\hline Month/years & 2012 & 2013 & 2014 & 2015 & 2016 & 2017 & 2018 \\
\hline January & 260 & 287 & 182 & 111 & 287 & 285 & 182 \\
February & 239 & 342 & 116 & 302 & 216 & 321 & 202 \\
March & 122 & 435 & 132 & 175 & 229 & 213 & 185 \\
April & 204 & 200 & 245 & 112 & 110 & 172 & 97 \\
May & 345 & 321 & 125 & 195 & 256 & 562 & 345 \\
June & 376 & 431 & 114 & 201 & 243 & 210 & 132 \\
July & 301 & 298 & 98 & 113 & 265 & 267 & 344 \\
August & 302 & 211 & 112 & 50 & 179 & 180 & 283 \\
September & 237 & 154 & 215 & 85 & 150 & 207 & 152 \\
October & 285 & 114 & 154 & 186 & 115 & 162 & 573 \\
November & 343 & 170 & 176 & 168 & 90 & 321 & 287 \\
December & 300 & 318 & 321 & 211 & 67 & 285 & 287 \\
Total no. of trips & $\mathbf{3 3 1 4}$ & $\mathbf{3 2 8 1}$ & $\mathbf{1 9 9 0}$ & $\mathbf{1 9 0 9}$ & $\mathbf{2 2 0 7}$ & $\mathbf{3 1 8 5}$ & $\mathbf{3 0 6 9}$ \\
Total tons & $\mathbf{2 3 1 9 8}$ & $\mathbf{2 2 9 6 7}$ & $\mathbf{1 3 9 3 0}$ & $\mathbf{1 3 3 6 3}$ & $\mathbf{1 5 4 4 9}$ & $\mathbf{2 2 2 9 5}$ & $\mathbf{2 1 4 8 3}$ \\
\hline
\end{tabular}

Source: Yobe State Environmental Protection Agency, 2012-2018. Note 1trip = 7 tons

Table 2: Descriptive statistics on solid waste collection from the year 2012-2018

\begin{tabular}{cccccccc}
\hline Years & \multirow{2}{*}{$\begin{array}{c}\text { No of } \\
\text { collection } \\
\text { months }\end{array}$} & $\begin{array}{c}\text { Monthly } \\
\text { collection }\end{array}$ & $\begin{array}{c}\text { Standard } \\
\text { deviation }\end{array}$ & $\begin{array}{c}\text { Standard } \\
\text { Error }\end{array}$ & $\begin{array}{c}\text { Sample } \\
\text { variance }\end{array}$ & Max. & Min. \\
\hline 2012 & 12 & 276.16 & 486.0206 & 134.7979 & 236216.1 & 376 & 122 \\
2013 & 12 & 273.41 & 492.7567 & 136.6661 & 242809.2 & 435 & 114 \\
2014 & 12 & 165.83 & 516.5365 & 143.2615 & 266810 & 321 & 98 \\
2015 & 12 & 159.08 & 518.8718 & 143.9092 & 269228 & 302 & 50 \\
2016 & 12 & 183.91 & 513.2545 & 142.3512 & 263430.1 & 287 & 67 \\
2017 & 12 & 265.41 & 496.8987 & 137.8149 & 246908.3 & 562 & 162 \\
2018 & 12 & 255,75 & 504.1783 & 139.8339 & 254195.7 & 573 & 97 \\
\hline
\end{tabular}

Source: Yobe State Environmental Protection Agency, 2012-2018

Table 3: Output generated by the ANOVA

\begin{tabular}{lcccccc}
\hline Source of variance & $\begin{array}{c}\text { Sum of } \\
\text { Squares }\end{array}$ & df & $\begin{array}{c}\text { Mean } \\
\text { Squares }\end{array}$ & F & P value & F Crit. \\
\hline Between Groups & 204861.7 & 6 & 34143.62 & 4.038473 & 0.001432 & 2.218817 \\
Within Groups & 651003.3 & 77 & 8454.588 & & & \\
Total & 855865 & 83 & & &
\end{tabular}




\subsection{Conclusions}

The analysis of waste collected shows that there was a decrease in the amount of waste collected from 23198 tons in 2012 to 21483 tons in 2018 during the period under review. The uncontrolled waste generation has led to the loss of the appealing nature of the urban landscape. Gashua town faces the same challenges as many other urban centers in Nigeria regarding infrastructure deficiency, population growth and lack of public awareness on the issue of waste management. This study revealed that inadequate infrastructure and funding are some of the most significant obstacles to successful waste management practices. Even though waste can be recycled to produce new products, these wastes are currently littering every available open space. The biodegradable waste could be composted to organic manure and could be used on the farms as manures. The agency is grossly understaffed as the so-called laborers are hired temporarily. Finally, the public attitude towards waste disposal is not helping matters. Despite the presence of waste collection bins, children especially dump their waste outside these bins. Enlightenment campaigns should be carried to educate the public.

\section{References}

Abbas, A. I. (2016). Between policy expectations and realities of poverty reduction efforts: An assessment of National Poverty Eradication Programme (NAPEP) in Yobe State, Nigeria. Journal of Social Science for Policy Implications, 4(1), pp. 37-62.

Abila, B. and Kantola, J. (2013). In Nigeria: Evolving Knowledge Management Solution. International Journal of Environmental, Ecological, Geological and Mining Engineering, 7(6), pp. $169-174$.

Adetunji, M. A., Atomode, T. I. and Isah, I. O. (2015). Assessment of Solid Waste Management in Lokoja, Nigeria, 7(2), 103-108.

Afun, S. (2006). Government Regulations and Legislations Will Ensure Sustainable Waste Management in Nigeria. International Solid Waste Association, 1-10.

Agunwamba, J. C. (1998). Solid waste management in Nigeria: Problems and issues. Environmental Management, 22(6), pp. 849-856.

Amasuomo, E. (2017). Solid Waste Management Trends in Nigeria Ebikapade Amasuomo and Jim Baird SEBE, Glasgow Caledonian University, Cowcaddens Road, G4 0BA, Glasgow, UK, 5(6), pp. $25-37$.

Amuda, O. S., Adebisi, S. A., Jimoda, L. A. and Alade, A. O. (2014). Challenges and Possible Panacea to the Municipal Solid Wastes Management in Nigeria. Journal of Sustainable Development Studies, 6(1), pp. 64-70.

Anestina, A. I., Adetola, A. and Odafe, I. B. (2014). Performance Assessment of Solid Waste Management following Private Partnership Operations in Lagos State, Nigeria. Journal of Waste Management, 2014, pp. 1-8.

Babalola, A., Ishaku, H. T., Busu, I. and Majid, M. R. (2010). The Practice and Challenges of Solid Waste Management in Damaturu, Yobe State, Nigeria. Journal of Environmental Protection, 01(04), pp. 384-388.

Birma, B.H. (2016). Assessment of Household Solid Waste Management in Gombe, Nigeria. Unpublished M.Sc Thesis, Department of Urban and Regional Planning, Ahmadu Bello University, Zaria, Nigeria

Chukwuemeka, E., Ugwu, J. and Igwegbe, D. (2012). Management and Development Implications of Solid Waste Management in Nigeria. Asian Journal of Business Management, 4(4), pp, 352-358. 
Djurfeldt, A. A., Sircar, S., Okonkwo, S. O., Orebiyi, J. S., Kadiri, F. A., Johnson, I. U. and Draft, F. (2017). Land fragmentation effects on technical efficiency of cassava farmers in South-West geopolitical zone, Nigeria. Cogent Social Sciences, 3(2), pp. 1-10.

El-Haggar, D. S. M. (2007). Sustainability of Municipal Solid Waste Management. Sustainable Industrial Design and Waste Management, pp. 149-196.

Imam, A., Mohammed, B., Wilson, D. C. and Cheeseman, C. R. (2008). Solid waste management in Abuja, Nigeria. Waste Management, 28(2), pp. 468-472.

Kulla, D. M. and Gukop, N. (2012). Municipal Waste in Nigeria Generation , Characteristics and Energy Potential of Solid, 2(2), pp. 84-88.

Metropolis, K., State, K., Tanko, S. M. and Sawyerr, H. O. (2018). Assessment of the Sustainability of Solid Waste Management in, 12(8), pp. 1-6.

National population Commission. (2010). Population Distribution by Sex and Class-size of Household, VIII.

Ogwuleka, T. C. (2009). Municipal Solid Waste Management in Nigeria. J. Environ. Health. Sci. Eng, 6(3), pp. 173-180.

Oluwaleye, M. O. (2012). Proposal for a new waste management system in Nigeria, 108. Retrieved from https://www.theseus.fi/bitstream/handle/10024/52188/OLUWALEYE MICHAEL OPEYEMI.pdf?sequence 05/07/2013

Schuh, R. G. and Languages, Y. HAUSA (Gashua Dialect). Russell The Journal Of The Bertrand Russell Archives.

United Nations, Department of Economic and Social Affairs, P. D. (2014). World Urbanization Prospects. United Nations, 12, 32. https://doi.org/10.4054/DemRes.2005.12.9

Uwadiegwu, B. O. and Chukwu, K. E. (2013). Strategies for Effective Urban Solid Waste Management in Nigeria. European Scientific Journal, 9 (8), pp. 1857-7881.

Walling, E., Walston, A., Warren, E., Warshay, B. and Wilhelm, E. (2004). Municipal Solid Waste Management in Developing Countries: Nigeria, a case study. Group 9, NTRES 314, Stephen Wolf, group 9 (April), 1-70.

WFP. (2016). Emergency Food Security Assessment in Gujba and Gulani LGAs, Yobe State, Nigeria Emergency Food Security Assessment Emergency Food Security Assessment in Yobe State, Nigeria, (October).

Yobe State Government, (YBSG). (2016). Yobe State Socio-Economic Reform Agenda (Yosera-IV) 2016-2020, 2016-2020

Cite this article as:

Saleh A. and Ahmed A., 2019. Solid Waste Management Practice and Challenges in Gashua, Yobe State, Nigeria. Nigerian Journal of Environmental Sciences and Technology, 3(2), pp. 298-303. https://doi.org/10.36263/nijest.2019.02.0139 